\author{
Maria Celina D'Araujo' \\ Júlia Petek ${ }^{2}$ \\ 1 Pontifícia Universidade Católica do Rio de Janeiro / Departamento de Ciências Sociais, Rio de Janeiro / RJ — Brazil \\ 2 Pontifícia Universidade Católica do Rio de Janeiro / Programa de Pós-graduação em Ciências Sociais, Rio de Janeiro / RJ — \\ Brazil
}

This article analyzes the profile of the public managers of four ministries: Finance and Planning, representing the economic area, and Health and Education, as examples of the social area. Based on empirical data, a comparison of the profile of the occupants of these senior positions from 1995 to 2012 is proposed. The research demonstrates the specificities of the recruitment pattern in these two areas of the bureaucratic field and shows that the public leaders of the economic area come from the most favored social sectors, present a more technical pattern and are less engaged in political, social and union matters. However, they are not intellectually superior in terms of qualifications. The data allow to discuss Bourdieu's theses on the elites of the bureaucratic field and help to demonstrate the myths about the greater academic qualification of the bureaucratic sectors of the economic and financial areas.

Keywords: management and advisory positions (DAS); public leaders; bureaucratic recruitment; bureaucratic field.

\title{
Recrutamento e perfil dos dirigentes públicos brasileiros nas áreas econômicas e sociais entre 1995 e 2012
}

$\mathrm{O}$ artigo analisa o perfil dos dirigentes públicos de quatro ministérios: Fazenda e Planejamento, representando a área econômica, e Saúde e Educação, como exemplos da área social. Baseado em dados empíricos, propõe uma comparação de perfil dos ocupantes desses altos cargos no período de 1995 a 2012. A pesquisa demonstra as especificidades do padrão de recrutamento nessas duas áreas do campo burocrático e evidencia que os dirigentes públicos da área econômica são provenientes de setores sociais mais favorecidos, apresentam padrão mais técnico e são menos engajados em questões de ordem política, social e sindical. Mas nem por isso são intelectualmente superiores em termos de titulação. Nossos dados permitem dialogar com as teses de Pierre Bourdieu sobre as elites do campo burocrático e ajudam a desmontar mitos sobre a maior qualificação acadêmica dos setores burocráticos da área econômica e financeira.

Palavras-chave: cargos de direção e assessoramento (DAS); dirigentes públicos; recrutamento burocrático; campo burocrático.

\section{La contratación y el perfil de los funcionarios públicos de alto nivel brasileños en las áreas económicas y sociales de 1995 a 2012}

El artículo analiza el perfil de los funcionarios públicos de cuatro ministerios: Finanzas y Planificación, en representación del área económica, y la Salud y la Educación, como ejemplos del área social. Basado en datos empíricos, sugiere una comparación del perfil de los ocupantes de estos puestos de responsabilidad en el período de 1995 a 2012. La investigación muestra la especificidad de lo patrón de reclutamiento en estas dos áreas del campo burocrático y evidencia que los funcionarios públicos de la zona económica provienen de los sectores sociales más privilegiados, tienen un carácter más técnico y son menos dedicados a las cuestiones de la orden política, social y sindical. Pero no por ello son intelectualmente superiores en términos de titulación. Nuestros datos permiten dialogar con las tesis de Bourdieu sobre las élites del campo burocrático y ayudan a desmontar mitos sobre la mayor calificación académica de los sectores burocráticos del área económica y financiera.

Palabras clave: gestión y posiciones de asesoramiento (DAS); funcionarios públicos; reclutamiento burocrático; campo burocrático. 


\section{INTRODUCTION}

For both Pierre Bourdieu (1989) and Reinhard Bendix (1996), the modern state is not inevitable. The state is a recurring phenomenon that, according to Bourdieu, emerges under certain circumstances and, for Bendix, can be explained as a sociological universal. Thus, the modern state cannot be considered as a "natural law" of history, and where it has emerged, some common characteristics were observed. One of them, and perhaps the most important one - as mentioned by Weber - is the creation of a bureaucratic, impersonal and specialized structure. According to Bourdieu (1989), the socio-genesis of the modern state can be explained through the establishment of the bureaucratic field throughout the history of several countries. This field is formed in a process of dispute with other fields of power, in their real or symbolic forms (Bourdieu, 1989; Thiry-Cherques, 2006).

Bourdieu and Bendix have a Eurocentric view of the state and for both authors the rational public administration was the element that made state control possible. Contrary to Bendix, Bourdieu (1989) understands that the configuration of the modern state is not based on relations between individual and power, but rather on disputes between various fields of human action such as the fields of politics, law, religion, culture, economy, and intellectual. The state would be a meta-field to which the various fields and capitals converge. This allowed the transition from the "house of the King", or house of the friends who are symbolically equal, to the "reason of state", i.e., to a bureaucratic formula with a specialized staff, counting on intellectual and cultural capital. Serving the king was no longer a matter of aristocratic personal ties. For the court to survive, new knowledge was required. The nobility itself legitimized the new category of officials, using public selection processes to choose among those coming from the best schools, the ones able to establish the standards of competence and expertise, those able to act with relative autonomy to enforce the state's reasons. In order to rule, the king needed reliable advisors with specific knowledge to organize the activities of the Crown, to carry out the taxations and to set up a routine for rules to be followed.

This was the period of transition from a culture where the nobility "was natural", defined by blood, to a "nobility of state", defined by education. This was a necessary and rational process for the court to continue to exist beyond the symbolic power of the nobles and clerics. The old court builds the new state through a vast bureaucratic field that allows it to maintain political and economic power. In his book Noblesse d'État (1989), Bourdieu demonstrates the strategies of reproduction that this nobility uses to maintain power, highlighting a relationship between the school title and the large state bureaucracy in France. Bourdieu is also concerned with the association of this new bureaucratic "nobility" and corruption, given the concentration of power, access, symbolic and real capital it controls (Bourdieu, Chiristen and Will, 2012).

Each field of human relations, in Bourdieu's view, forms its elites with social, intellectual, political and other types of capital that are not common to the whole society. In addition, each field forms its agents, rules and institutions. The bureaucratic field has its own identity, has a habitus that allows to know rules, objects and disputes. It has practices, social spaces and structure, specific objectives and is relatively autonomous (Simione and Matos, 2017).

In his article Esprits d'État, Bourdieu (1993) argues that modern bureaucracy is driven by the principle of universalization and by a dispute over the monopoly of this 'universal'. These "nobles" should not, therefore, make private use of public resources, practice influence peddling and act for their own benefit. 
The ethos of a bureaucratic elite in France that could be drawn by personal interests is the topic studied by Suleiman (1978). The author argues that since the beginning of the twentieth century the French administrative elites have advocated a state guided by principles of centralization, regardless of government's left or right ideology inclination, or conservative or reformist views. Therefore, these elites defend their personal interests and take time to adhere to the changes toward decentralization proposed by François Mitterrand's socialist government, from 1981 to 1995 (Suleiman, 1978:176). Both Suleiman (1978) and Bourdieu $(1989,1993)$, emphasize the existence of a bureaucratic field with its sociological and cultural specificities.

This article is part of the studies discussing the bureaucratic field in Brazil, analyzing public managers, as defined throughout the work.

\section{THE DEBATE IN BRAZIL}

The bibliography that analyzes the high public administration in Brazil since the 1930s has consistently stated that the economic areas related to industrial development has technically superior personnel in comparison to other areas of the government. Even when considering that industrialization has not been the most urgent issue in Brazil in recent decades, the economy has been one of the most important areas of government action, especially in view of anti-inflationary and growth policies, and continues to receive attention from the experts. The purpose is to show whether this distinctive pattern continued with the beginning of the democratic period in 1988 and to see what its indicators are. We chose to start from the period 1995 to 2012, looking at the Ministries of Economy and Planning, representing the economic area, and the Ministries of Health and Education, as examples of the social area.

The international literature on high public administration in Europe and the United States, including the literature that is not based on Bourdieu's work, deals with the subject taking into account the issues of the State as a whole, the relationship between powers, between economy and politics, education, capacities, ideology, professionalism, merit and meritocracy, and especially whether Weber's idea of bureaucracy is exhausted or not. There are no studies with this scope in Brazil. The topic has been approached specially by the relationship between the state and economic development (Lafer, 1975; Geddes, 1994; Nunes, 1997; Schneider, 1994). Following the state reforms of the 1990s, the discussion on the profile of the new high-ranking officials who became public managers (Longo, 2003) was resumed. But in this case it was marked the difference between the bureaucracy of the economic area in comparison to others, although there was no specific detail on this differentiation (Loureiro, Abrucio and Rosa, 1998; Lopez and Praça, 2015).

Important distinctions can be observed when comparing national and international studies. In 1981, Aberbach, Putnam, and Rockman published a book on the composition, perception, and functions of high bureaucracy in seven countries in Europe and the United States. It was a long quantitative and qualitative research of 10 years of work, which identified the degree of political involvement of the high bureaucracy, its education, ideology, relations with the executive branch and with the members of Congress. The countries studied were England, France, Germany, Italy, the Netherlands, Sweden and the United States. The book became a classic by showing that, even with variations in each of the countries studied, these high-ranking bureaucrats were not simply followers 
of orders dictated by politicians. They collaborated in policy formulation, expressed their preferences, dialogued with the government, parties or ministers. In short, they were an elite of top management that escaped increasingly from the Weberian idea of bureaucracy.

Years later, new research revisited several of these groups confirming the tendencies pointed out in earlier studies. The results were published in the journal "Governance" in 2003 addressing four of these countries (Great Britain, United States, Sweden, Germany) and included Belgium. In the introduction of this issue of the journal, Aberbach (2003) points out that the authors in this new round of research concluded that the traditional role of high level managers is to provide advice, expertise and historical memory to the politicians who hold important positions in government. These managers come from upper and upper middle classes, with higher education generally from the best universities of their countries, they consider themselves to be both counselors and administrators, and generally feel comfortable with the political aspects of the positions they occupy.

Even with the peculiarities of each country, the studies did not stress a differentiation between specific areas where the bureaucracy is in place, but almost always they have considered bureaucracy as a whole. In Bourdieu's words, the bureaucratic field is studied more comprehensively than what is observed in the daily operations.

In Latin America, Barbara Geddes (1994) as well as Ben Schneider (1994) are pioneers in the study of state capabilities offered by the bureaucracy. They focus more on the Brazilian case taking into account the relations between bureaucracy and development. Both understand that Brazil was the most successful country in the region, in economic terms, especially concerning industrialization. The Brazilian political elite, always averse to major reforms, allowed a qualified bureaucracy to undertake quality changes in the economic sector without hurting politically dominant interests.

Corroborating the conclusions of Nunes (1997) and Lafer (1975), Geddes (1994) states that in Brazil, and in some neighboring countries, insulated areas were created in the sector of development so that the clientele system could operate within other sectors. Based on similar arguments, Peter Evans $(1993,2004)$ analyzes the Brazilian industry and its problems in social and administrative aspects. Schneider (1994), in turn, studied careers in the public service in Brazil in the years 19701980 and concentrated analysis on industries. The author concluded that personal appointments based on technical capacity prevailed over institutional criteria in structuring the power in Brazil when it comes to industrialization. Schneider (1994) observes that the success of industrial policy was due more to the work of appointed personnel than to the state's bureaucratic organizations. Thus, in the case of Brazil, during the military dictatorship, little institutionalized bureaucracies produced stability in the policies of industrialization. The author argues that this was possible thanks to the technical excellence of the appointed personnel related to specific projects.

Mathias (2004) examines the level of militarization of the economic bureaucracy during military administrations (1964-1985) and, like Schneider, concludes that the economic area was the most preserved from clientelistic, civil and military pressures. The author shows that in the period, without considering the position of minister, the rate of militarization in the Ministry of Economy was 3.2\%, while Communications and Transportation reached $68.7 \%$ and 50\%, respectively. This means that, in discretionary times, the economic bureaucracy has been preserved from the pressures of civilian or military power-holders. 
Also looking at the Brazilian case, Loureiro, Abrucio and Rosa (1998) found that the high federal bureaucracy of the Ministry of Economy in the period of the Fernando Henrique Cardoso government worked in a hybrid way, using positions both of political and bureaucratic nature, with roles similar to police-makers. This corroborated the ideas present in the work of Aberbach, Putnam and Rockman (1981). According to Loureiro, Abrucio and Rosa (1998:50), historically, and because of its very institutional nature, the technical aspects in the Ministry of Economy prevail over political aspects, leading to a differentiation of configuration between economic ministries and spending ministries. In the words of Bourdieu (2012:62, 655), a differentiation between financial ministries and spending ministries, the latter are a result of the expansion of the Welfare State.

In this same work, the authors analyze the configuration of the three highest levels of management positions of the Ministry of Economy in relation to all the managers of the federal government, noting that, at the time, they had a higher than average level of schooling, and that they came from the personnel working in the lower positions of the federal government's executive branch, although not necessarily of the Ministry of Economy. They conclude that appointments for high-level positions present a political nature, in the sense of affinities between politicians and bureaucracy, although the Ministry of Economy is still considered the one with the most technical appointments (Loureiro, Abrucio and Rosa, 1998).

In a recent work, Loureiro, Olivieri and Martes (2010) return to the discussion about the relationship between politics and bureaucracy, and the analysis of policy-makers in Brazil, also focusing on the consolidation of bureaucracy as a relevant actor in the decision-making process in economic policies. Regardless of the positive or negative consequences of such a process, they demonstrate how a more technical pattern is maintained after the re-democratization of 1988. They observe a monopoly of economic decisions by certain bureaucratic segments, not only of career officials (mainly the Central Bank and Ministries of Economy and Planning), but also professionals from the private sector (university and financial market). These areas would remain more restricted to the influence of Congress, political parties and popular pressures.

On the other hand, Lopez and Praça (2015), analyzing the criteria applied by members of Congress and political parties for the distribution of Management and Advisory positions (known as DAS in the position and pay structure of the federal government executive branch) in Brazil, argue that the division of the appointed positions in the federal executive branch responds to the logic of coalition presidentialism, in which the president uses these appointments to compose a majority in Congress. According to the two authors, however, there is no univocal logic, but variations between areas of governments and between governments. Within these variations, the authors highlight some characteristics. First, there are areas of government in which the space for party appointments is smaller, as is the case of the Ministry of Economy. These areas would be considered "bureaucratic islands", that is, areas that "enjoy greater autonomy in the selection and recommending of names" (Lopez and Praça, 2015:38). These 'islands', typically found in the economic areas of governments, require technical knowledge and have a greater administrative tradition based on career public officials. Other areas, particularly areas of social policies and infrastructure, are more subject to the influence of party disputes in forming the personnel in management roles. As a general conclusion on the appointments to the DAS positions, the authors say that, despite the different situations, the data show that there is, in general, a bigger technical field in the economic area. Thus, there is a combination of technique and politics for the appointment of these positions. This means that a minimum technical qualification for appointments is required, even if they are politically influenced. 
As we have seen so far, the debate in Brazil overestimates the economic bureaucracy at the federal level and implies that there is a higher educational capital in this area in comparison to other sectors of the public administration.

\section{METHODOLOGY}

This study empirically observes the distinction in the recruitment and profile of the Brazilian public managers of the Ministries of Economy and Planning; and the Ministries of Health and Education. The period analyzed was from 1995 to 2012, covering the governments of Fernando Henrique Cardoso (1995-2002), Lula da Silva (2003-2010) and the first two years of Dilma Rousseff's term (2011-2012). These managers occupied senior Management and Advisory positions - levels five and six (DAS 5 and 6) and the so called "Special Nature" (NE) positions of the federal government executive branch's position and pay structure.

According to the statistical bulletin of personnel of February 2016, when the qualitative research was concluded, there were about 100 thousand appointed positions in the federal government's executive branch. Of these, 21,700 were management and advisory positions (DAS) divided between levels 1 to $6 .{ }^{1}$ The object of this study, those of level 5 counted on 1,043 people, those of level 6, 210, and the positions of Special Nature, $86 .^{2}$

The Management and Advisory positions were the result of the administrative reform of 1967, expressed in Decree-Law No. 200. These positions regained importance the State reform process led by the Ministry of Administration and State Reform (Mare) in 1995.

In order to fill these positions, Decree No. 5,497, of 2005, determined that $75 \%$ of positions DAS levels 1, 2 and 3 and $50 \%$ of positions DAS 4 should be filled by public servants (active, inactive, from executive, legislative and judiciary branches and from other federative spheres). The DAS levels 5 and 6 and positions of Special Nature would be freely available for appointment.

This study focuses on these three levels, considering the four ministries mentioned, denominating this group as public managers. They are people who have served as Secretaries of State, SecretariesGeneral of Ministries, Advisors to, among others, Ministers and to the President.

In line with the research by D'Araujo (2009) that counted as well on the support of the Ford Foundation, this research was conducted through interviews and questionnaires answered in person or written, over 10 years. In addition, biographical information was extracted from official sources such as the federal government official gazette, the Diário Oficial da União.

This study analyzes 268 public managers in four ministries, as described in table 1 below. It corresponds to $26 \%$ of the interviewees, which counted 1,030 public managers working in all ministers. The number of appointed positions to be filled by public managers in each of the four ministries has varied from one government to another. The sample is, however, expressive and consistent when considering that the number of positions for each ministry studied was between 40 and 60 in the four ministries, based on Lula da Silva's first government (D’Araujo, 2009:140). Taking this into account,

\footnotetext{
${ }^{1}$ Available at: <www.planejamento.gov.br/assuntos/gestao-publica/arquivos-e-publicacoes/BE $>$. Accessed on: 16 June 2016.

${ }^{2}$ The bulletin considers as 'Special Nature' the positions of president, vice-president and ministry. These cases were not considered in the research.
} 
and considering the lowest rate of responses in the Ministry of Economy in the first two years of Dilma Rousseff's term considered in this study (2011-2012), the following analysis is methodologically sound and consistent.

TABLE 1

TOTAL PUBLIC MANAGERS RESEARCHED FOR THE MINISTRIES OF ECONOMY, PLANNING, HEALTH AND EDUCATION (1995-2012)

\begin{tabular}{lcccc} 
& Cardoso & Lula & Rousseff & Total per ministry \\
\hline Ministry of Planning & 33 & 33 & 24 & 90 \\
Ministry of Economy & 23 & 44 & 8 & 75 \\
Ministry of Health & 11 & 26 & 14 & 51 \\
Ministry of Education & 11 & 26 & 15 & 268 \\
\hline Total per government & 78 & 129 & 61 &
\end{tabular}

Source: Elaborated by the authors.

The choice of these four ministries and the bodies attached to them was for three reasons. The first is related to the participation of these ministries in the Federal budget. The Ministries of Health and Education were selected as representatives of the social area, since, after Social Security, they represent the largest budgets of the country. In 2015, Health received 7.15\% of the budget and Education, $6.1 \%$, representing, respectively, the first and second place among the ministries. Soon after came the Ministry of Defense with 4.82\% and Social Development and Fight Against Hunger with 4.45\%. The Ministries of Planning and Economy, represented here as ministries of the economic area, received, respectively, $1.26 \%$ and $1.88 \%$ (LOA, Law No. 13,115, of 20 April 2015). The second reason is that the two groups of ministries have opposing roles. Economy and Planning are responsible for the collection and the budget of the federal government, and the other two are the ministries that, by nature, spend more resources. Finally, the third reason is the importance, in our view, of understanding how the findings add to or challenge the current analyzes.

\section{COMPARING THE FOUR MINISTRIES: ECONOMY, PLANNING, HEALTH AND EDUCATION}

In this section the objective is to demonstrate, based on empirical data, whether, in democratic times, a differentiated pattern was maintained in the recruitment and profile of public managers in the Ministries of Economy and Planning, regarded as 'financial', and Health and of Education, representing the social area, regarded as 'spending' ministries. This section will also explore whether there were differences in terms of recruitment and profile of public managers in the governments of the three presidents during the analyzed period. 
To achieve these objectives, we worked with six data sets, some of them linked to social, economic, political, educational, and administrative capital, that is, a specifically bureaucratic field: 1) regional recruitment, with an emphasis on endogenous recruitment in Brasilia; 2) professional relations of the managers with the government body they come from before occupying the appointed position, with other sectors of the federal, state and municipal public service, and with private firms; 3 ) schooling of the managers and their parents; 4) political party affiliation; 5) trade union affiliation; and 6) relations with social movements. The study takes into consideration the differences between the governments, bringing attention to the fact that, even with some particularities found in the period of Lula da Silva's administration, the pattern of differentiation in the economic area has remained, but not for the reasons that the literature has pointed out.

\subsection{RECRUITMENT OF PUBLIC MANAGERS}

The study identified a prominence of public managers recruited in the Southeast region of Brazil, which is a socioeconomic cluster and holds the largest share of national income and the highest concentration of universities. The second most represented region in this analysis is the Central-West (Brasília) that increases its participation during the governments of Cardoso and Dilma Rousseff, indicating a growing internal recruitment in federal bureaucracy, a phenomenon that needs to be further studied. This regional distribution, which can be observed in graph 1, is especially striking in the economic area, although there are some differences between the various governments.

GRAPH 1 MINISTRIES OF PLANNING AND ECONOMY: PUBLIC MANAGERS PER REGION (\%) 1995-2012

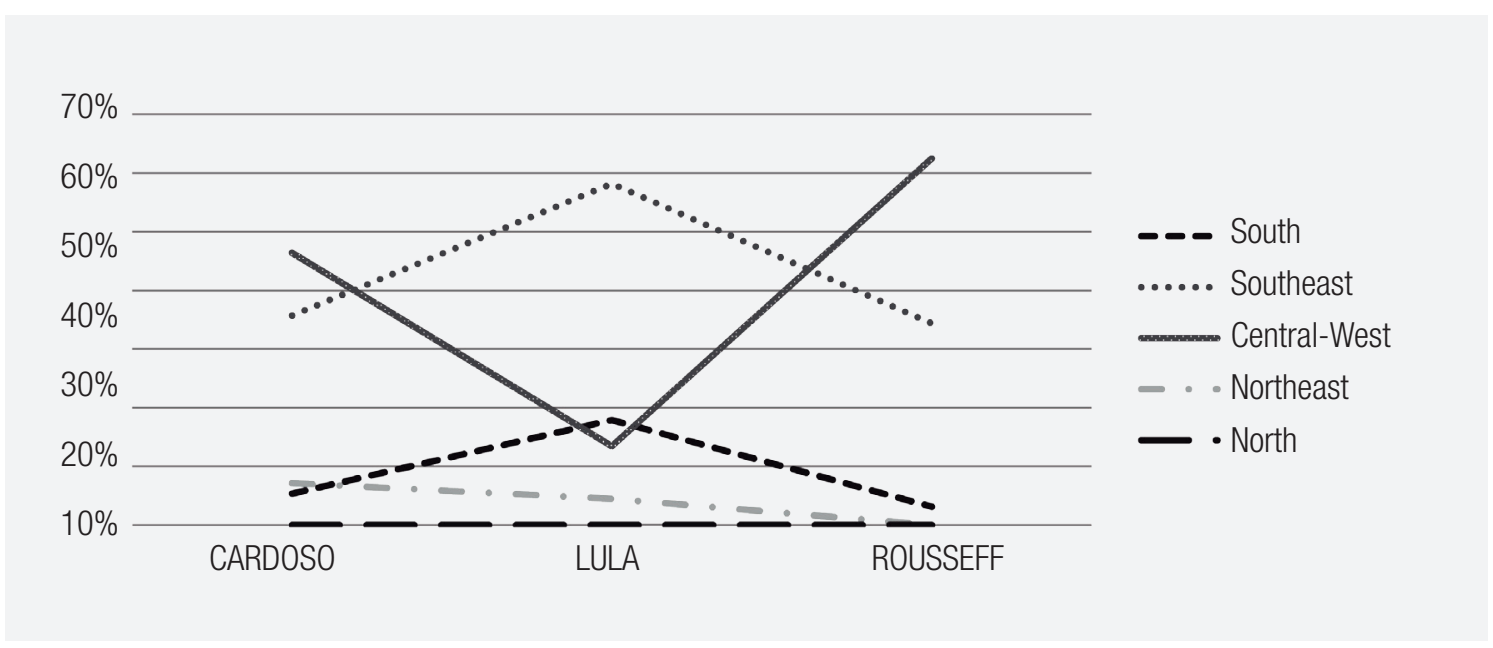

Source: Elaborated by the authors.

In the case of the Ministries of Health and Education, as shown in graph 2, the Southeast predominates. There is a more homogeneous distribution between regions, although the North is much less represented. It was also in the Lula da Silva administration that the most balanced recruitment 
among all the regions in the social ministries was observed. The next president, Dilma Rousseff edges away from the pattern shown by her predecessor. Despite this, unlike the previous graph, we can see a more egalitarian regional distribution in the governments of the Workers' Party (Lula da Silva and Rousseff), which is most likely a reflection of the local strength of the parties and the class movements.

GRAPH 2

MINISTRIES OF HEALTH AND EDUCATION: PUBLIC MANAGERS PER REGION (\%) 1995-2012

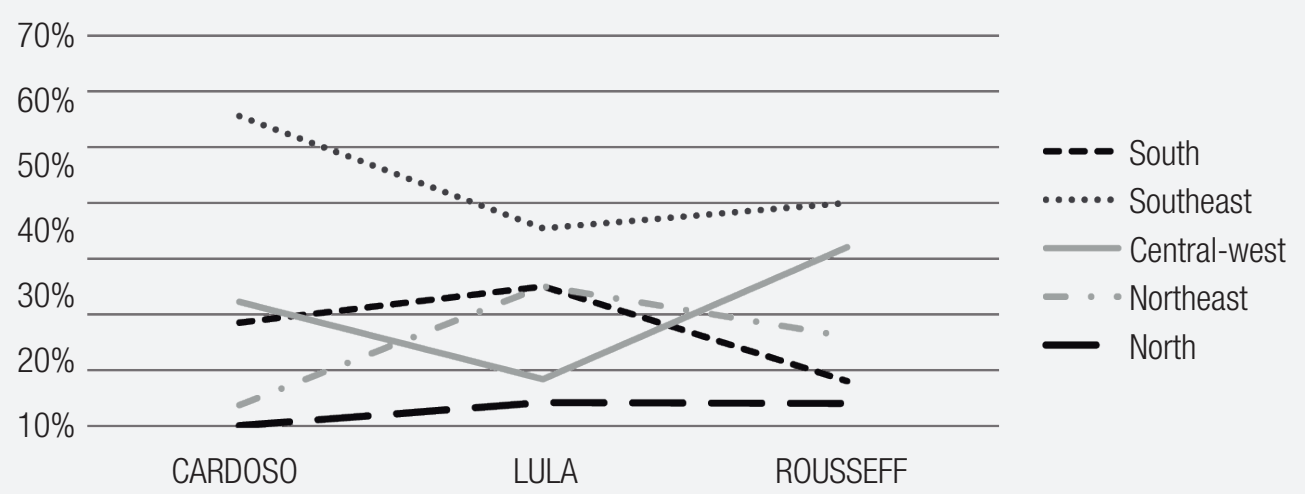

Source: Elaborated by the authors.

\subsection{RELATIONS BETWEEN PUBLIC MANAGERS AND THE PUBLIC AND PRIVATE SECTORS}

Another way to study recruitment is to examine what kind of professional activity these managers performed before being appointed. An important indicator for assessing work experience is the type of connection they previously had with the public service. To that end, we asked the respondents if they had any relation with the public service and, if so, what type of relation. As a general criterion, the official data present four situations in which the origin of the public managers can be classified: public servant of the body in which they were appointed as managers; public servant of another body and/or sphere of government (state or municipality); non public servants; and retirees, whose presence has gradually disappeared and so are not considered in our data. For this analysis, graphs 3 and 4 show marked differences between the two groups of ministries. In the financial area, Lula da Silva privileged internal recruitment, while Cardoso and Rousseff recruited internally and externally, in an even way. On the other hand, the participation of people from the private sector (non public servants) in the financial ministries remains significant throughout the three governments, albeit with a small decrease: from $32 \%$ in the Cardoso government to $25 \%$ in the Rousseff's.

Regardless, once again, of the particularities observed in Lula da Silva administration, there is a balanced distribution pattern among the three governments concerning the recruitment of public officials to the economic area. We assume, therefore, that the ethos of the bureaucratic field is more rooted in this area, but necessarily, as we shall see, it is not a more educated elite. The same relative 
stability occurs in the social area with the specificity that the recruitment in other bodies or spheres has always been predominant.

GRAPH 3 MINISTRIES OF PLANNING AND ECONOMY: PUBLIC MANAGERS PER TYPE OF PROFESSIONAL RELATION (\%) 1995-2012

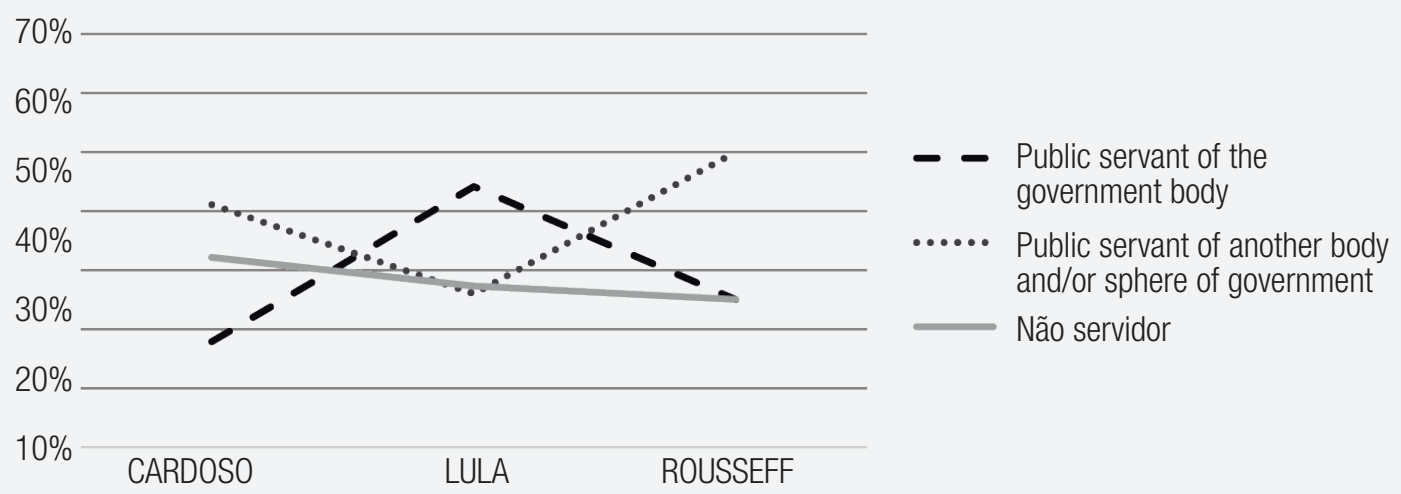

Source: Elaborated by the authors.

GRAPH 4 MINISTRIES OF HEALTH AND EDUCATION: PUBLIC MANAGERS PER TYPE OF PROFESSIONAL CONNECTION (\%) 1995-2012

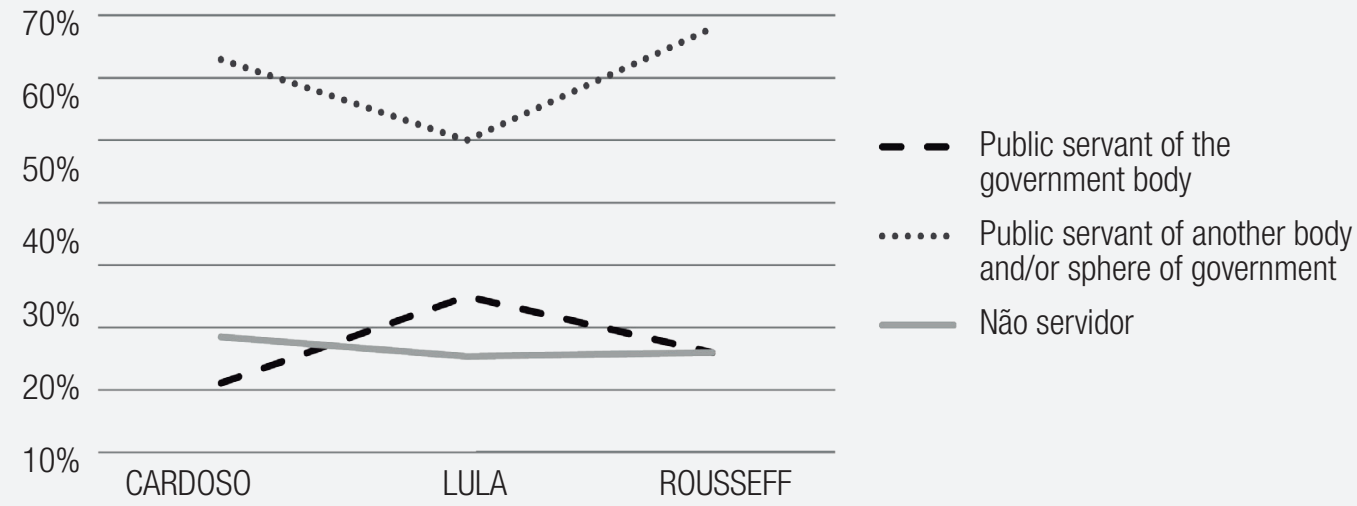

Source: Elaborated by the authors. 
Graph 4 shows that most public managers recruited to work in social ministries were recruited from other bodies. This leads to question from which spheres, municipality, state or federal, these managers are coming from.

The first finding is that among the public servants of the economic area, the federal sphere is the most frequent origin of technicians to fill the managerial appointed positions in the Ministries of Planning and Economy, contrasting with what happens in the two other ministries. The municipal sphere appears in the Lula da Silva administration, with a strong incidence in the Ministry of Health, showing a growth tendency in the Rousseff government. In the economic areas, practically all the managers come from the federal public service, with a small decrease in Lula da Silva administration. That is, although the public managers appointed to the economic area did not come from these two ministries, they had already worked in the federal government, indicating that they must belong to more consolidated and tested careers within the public service. In this sense, they can be considered more technical. In the social area (Health and Education), it is clear the decreasing trend in recruitment in the federal sphere since the Cardoso administration.

Even with the differentials observed in the Lula da Silva administration, it is possible to see that the Southeast and Brasília are the main region of origin of managers in the economic area and that the Southeast is isolated as the main provider of managers in the social area, although this area shows a greater presence of managers from other regions. In short, in the economic area, managers coming from the public sector were already employed in the federal public service, which should be an indicator of more established careers and more consolidated knowledge and, perhaps, more inclined to work insulated. On the other hand, the greater presence of public employees from states and municipalities in the social area may indicate the greater capillarity of this sector.

The aim of this set of indicators is to indicate a differential of recruitment of managers for the economic area. The next section shows the distinctions in relation to manager's education.

\subsection{MANAGERS' EDUCATION}

The analysis of the education of managers and of their parents helps to observe their class situation and social mobility, considering that the level of education is an indicator of social class. In general, we observe that the level of formal education of public managers in Brazil is high. As shown in graphs 5, 6 and 7 separated by governments, practically all of them completed an undergraduate program, while only $11.3 \%$ of the population have this level of education, according to the 2010 IBGE census published in 2012.

In the Cardoso administration, the highest education level is observed in the Ministry of Education and the lowest in the Ministry of Economy, an area considered to be more professionally efficient. In the Lula da Silva administration, this situation practically repeats, although the presence of managers with only complete higher education is recorded in all ministries. 


\section{GRAPH 5}

\section{CARDOSO ADMINISTRATION: PUBLIC MANAGERS, LEVEL OF EDUCATION (1995-2002)}

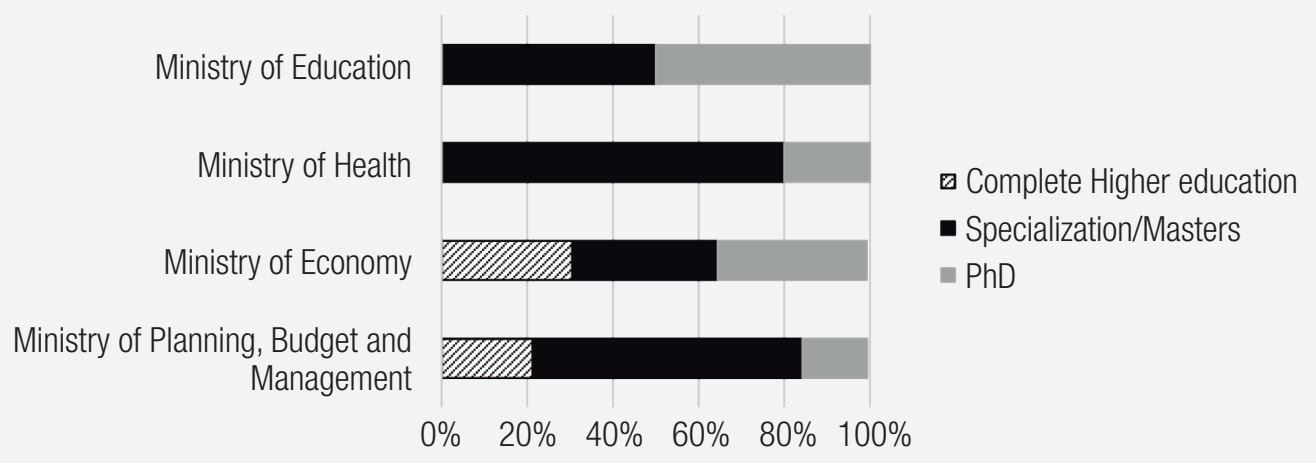

Source: Elaborated by the authors.

\section{GRAPH 6 LULA ADMINISTRATION: PUBLIC MANAGERS, LEVEL OF EDUCATION (2003-2010)}

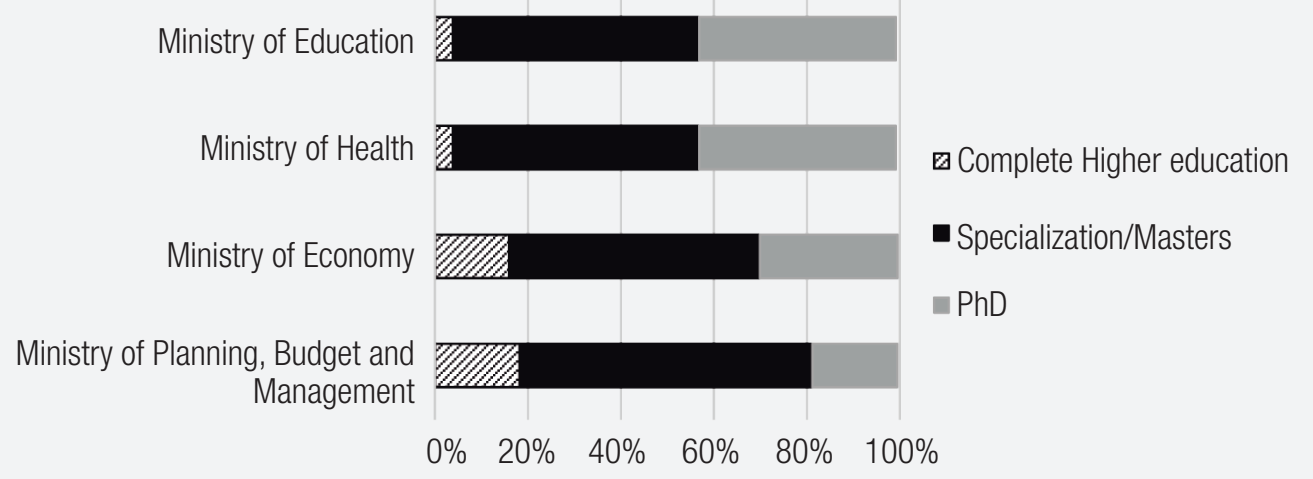

Source: Elaborated by the authors.

In the Lula da Silva administration, managers in the Ministry of Education remain the most schooled alongside the Ministry of Health. Regarding the Ministries of Economy and Planning, they present a higher percentage of managers with higher education in comparison to the other ministries, even though there are more managers with graduate degrees when compared to the previous government. On the whole, however, the Ministries of Economy and Planning are the ones with the lower percentage of managers with specialization/masters and $\mathrm{PhD}$, which disenfranchise a 
narrative of a more intellectually prepared elite, when taking into account the academic degrees and the intellectual capital.

GRAPH 7 ROUSSEFF ADMINISTRATION: PUBLIC MANAGERS, LEVEL OF EDUCATION (2010-2012)

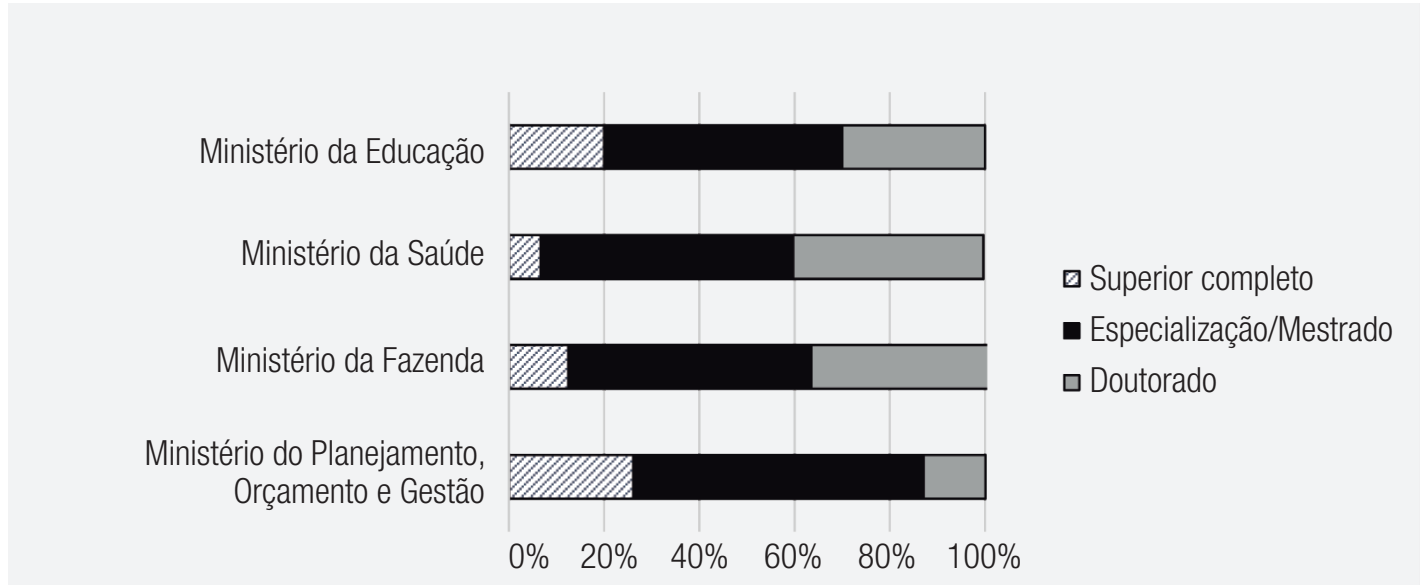

Source: Elaborated by the authors.

Under Rousseff's administration, the number of managers who only have complete higher education remains high. Overall, the percentage of managers with PhD's decreases, although the country produces more doctors each year. The Ministry of Health has the highest levels of education in terms of academic degree: $93 \%$ of the public managers hold at least one postgraduate degree. In the Ministry of Economy, the percentage of people with specialization, masters and doctorates increases, the highest in the three governments, but the same is not seen for the Ministry of Planning.

In general, it is possible to emphasize that in all governments, the Ministries of Education and Health are those with the highest percentages of public managers with postgraduate degrees. The 'financial' ministries, on the other hand, in all three governments have lower education rates and this may be an indicator of more technical careers or more isolated bureaucracies.

\subsubsection{EDUCATION OF THE PUBLIC MANAGERS' PARENTS}

The level of education of the public managers' parents in the four ministries can be an indicator of class origin. In this study, we emphasize those with complete higher education to those with PhDs. At once, attention is drawn to the fact that the managers at the Ministries of Economy and Planning come from families where the father has higher education, a symbol in general of belonging to the middle classes. The Ministry of Economy can be highlighted as being, symptomatically, the one with the highest number of parents with superior education. However, this family capital did not translate into greater intellectual capital. 


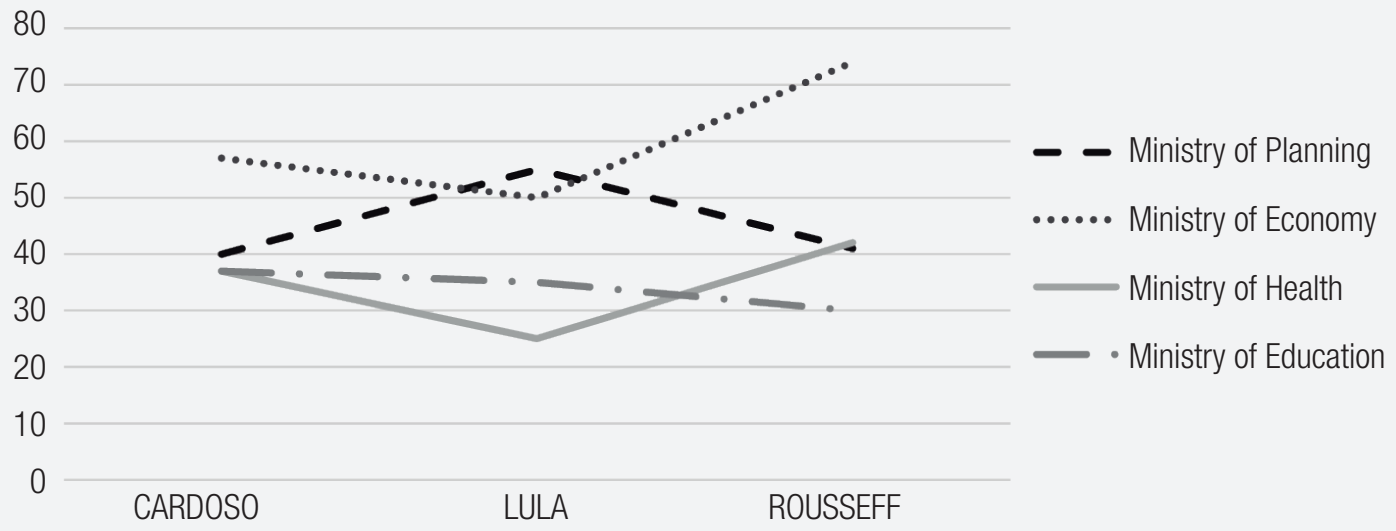

Source: Elaborated by the authors.

\subsubsection{EDUCATION OF THE PUBLIC MANAGERS' MOTHERS}

In the case of the education of public managers' mothers, the study uses the same categories of analysis as for schooling of the managers' father, that is, those who have completed higher education or who have advanced to hold specialization, masters or a $\mathrm{PhD}$. The most striking finding is that women are less educated, as one would expect for the generation under analysis. However, the most educated mothers were those whose children were managers at the Ministry of Economy.

\section{GRAPH 9 PUBLIC MANAGERS' MOTHERS WITH EDUCATION LEVELS OF HIGHER EDUCATION TO PHD} PER GOVERNMENT (\%) 1995-2012

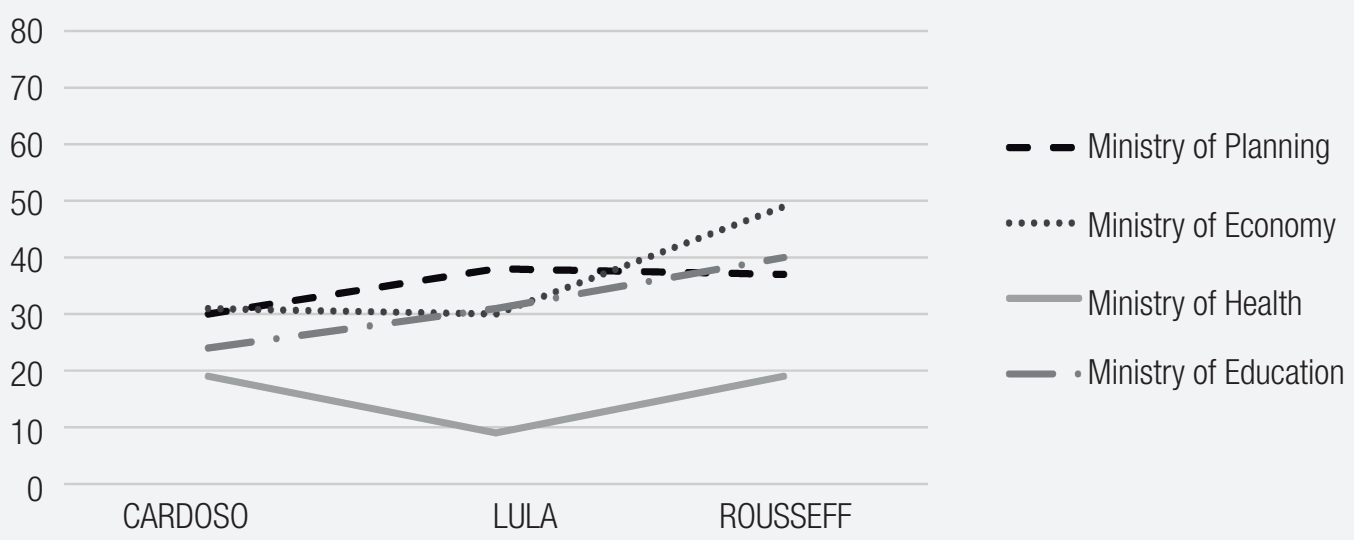

Source: Elaborated by the authors. 
Additional information to be drawn from these data is that during the 20 years covered in the study, it can be noted that the mothers' education increased, except for the case of the Ministry of Health. This indicator, which helps to understand the origin of the managers' social class, also helps to explain the expansion, albeit slow, of the educational levels of the country's women and the possibilities of social mobility.

\subsection{MANAGERS' POLITICAL PARTY AFFILIATION}

Two variables were investigated for the public managers' profile in terms of politics: affiliation to political parties upon taking office and which parties were they affiliated to. Our data show that among all the occupants of the positions DAS 5 and 6 and NE during the Cardoso government, about $18 \%$ were affiliated to political parties. That number rose to $25 \%$ in the Lula da Silva government and dropped to $23.5 \%$ in the Rousseff government. From these data, it can be inferred that politicalpartisan capital has little weight, although it was higher in the Lula da Silva administration.

For the four ministries studied, there are 56 public managers affiliated to political parties, that is, $21 \%$ of the total of 268 managers that formed the sample: 17 of the 78 researched in Cardoso's administration; 26 of the 129 in Lula da Silva's and 13 of the 61 in Rousseff's. The percentage distribution of managers affiliated to political parties in the four ministries is shown in graph 10. The most striking point from all the governments is the lack of affiliation in the Ministry of Economy compared to the other ministries.

\section{GRAPH 10 PUBLIC MANAGERS AFFILIATED TO POLITICAL PARTIES WHEN TAKING OFFICE, PER MINISTRY AND GOVERNMENT (\%) 1995-2012}

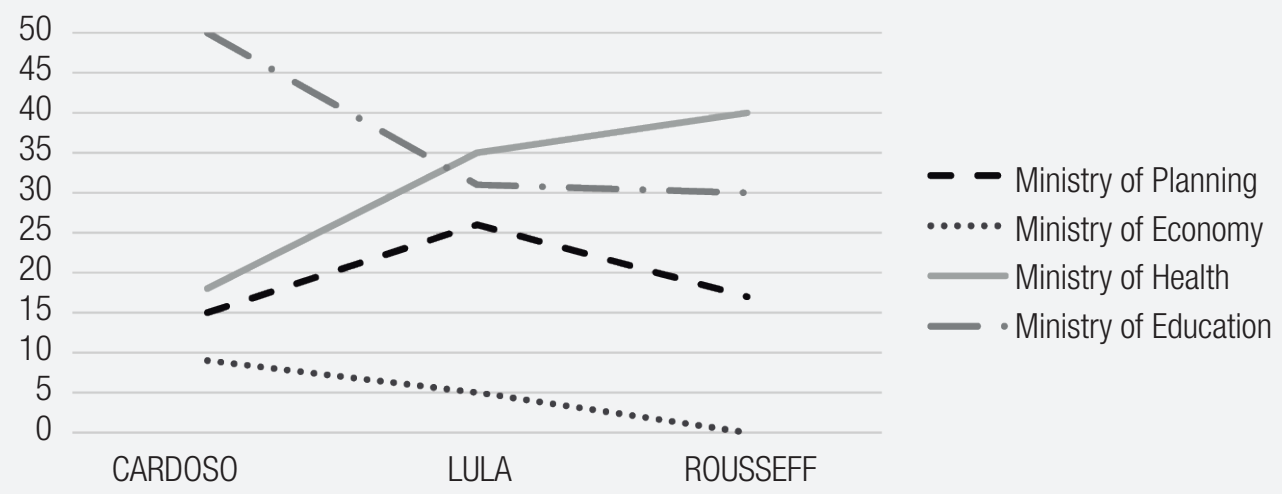

Source: Elaborated by the authors.

As for the parties the managers were affiliated when they took office, the differences between the four ministries and the different governments are also striking. In the Cardoso government, $48.8 \%$ of the party-affiliated managers belonged to the president's party (Brazilian Social Democratic Party); 
in the Lula da Silva and Rousseff administration, the percentage of managers of the president's party (Workers' Party) was of $80 \%$ and $81.8 \%$ respectively (D’Araujo, 2009).

It is well known that party affinities are not simply defined by affiliation and that there is a historic adherence of federal public servants to the Workers' Party is a widely publicized phenomenon. In any case, according to our data when the Workers' Party was in power, the party participation in the federal government became more intense. This makes sense, considering that we are examining appointed positions in a government whose party had cultivated social valorization of its personnel and of its activists among public servants. Even if partisanship is not incompatible with technical capacity and knowledge, the Ministry of Economy was the one that had the lowest percentages of managers with party affiliation in all the governments. On the other hand, the Ministries of Health and Education are those with the highest presence of party affiliates with the three presidents.

There was, in fact, a wider party-oriented distribution of appointed positions during the three governments, but this percentage never exceeded $25 \%$ and was always lower in the economic area. This is an area where managers showed to have fewer academic degrees and less relation with partisan politics. This latter characteristic is closer to a state bureaucracy, apart from the lack of education superiority which is important in forming the nobility of state.

\subsection{MANAGERS' TRADE UNION AFFILIATION}

With the arrival of Workers' Party to power, the theme of the connections between the bureaucracy and sectors of trade unions gained unprecedented prominence. Not rarely, the expression "trade union republic" was heard in the press. This section will present some information about the manager's union affiliation, assessing how this aspect is real and, if so, whether it is equally disseminated among the four ministries.

Graph 11 is surprising. During the almost 20 years examined, the Lula da Silva government presented the highest number of public managers affiliated to the trade unions. The Ministry of Economy, however, was the one that recruited the lower number of managers affiliated, while the Ministry of Planning remained stable. Throughout the entire period, the Ministry of Health gathered the highest number of managers affiliated to trade unions, which probably reflect the corporate strength and political capital of organizations linked to public health. The participation of people related to unions in the Lula da Silva government is an empirically verifiable fact, as well as the discontinuity of this pattern with Rousseff. It is possible to conclude that Lula da Silva paid back the political capital earned during the period in which he was a union leader and that had been so important in his electoral history. This commitment, which did not exist in the case of Cardoso, practically disappears in Rousseff's administration.

Similarly, and as might be expected, managers affiliated to trade union federations were more present in the Lula da Silva administration. However, this did not apply to the Ministries of Economy and Planning, different from what is observed in the Ministries of Health and Education. This shows that the presence of members of trade unions in the government was not widespread in all the ministries, even when considering the large participation of this group in the Lula da Silva government. Graph 12 is self-evident: a near perfect triangle that once again approximates the administrations of Rousseff and Cardoso. 


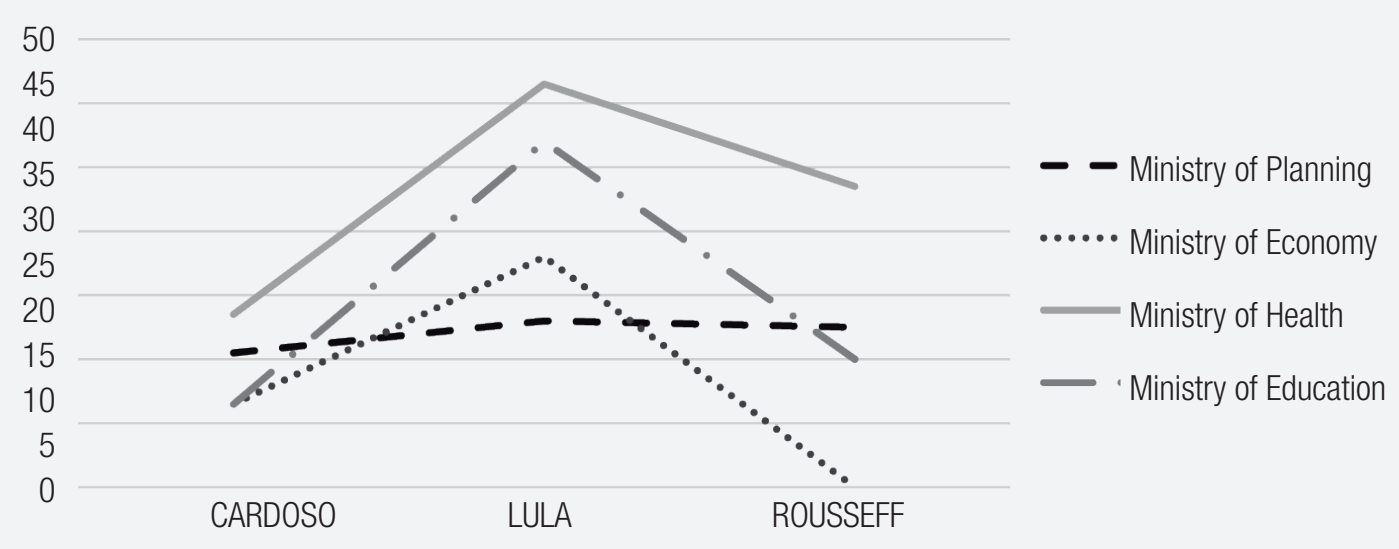

Source: Elaborated by the authors.

GRAPH 12 PUBLIC MANAGERS, MEMBERS OF TRADE UNION FEDERATIONS, PER GOVERNMENT (\%) 1995-2012

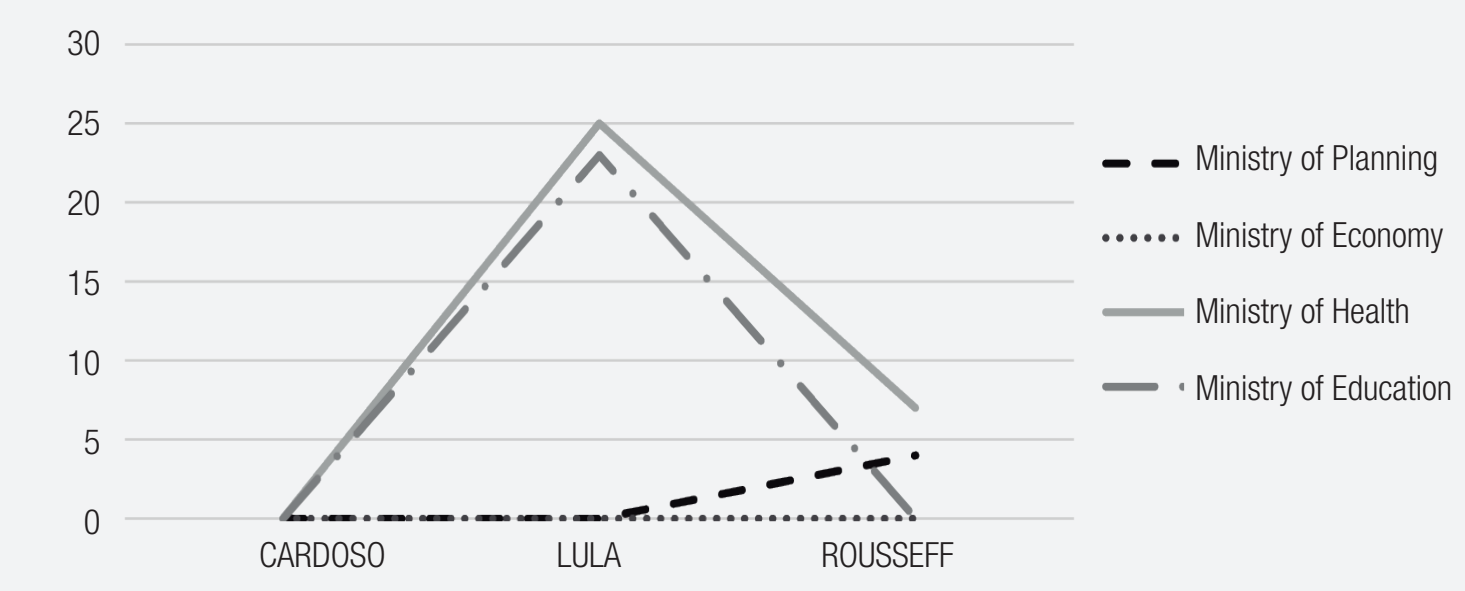

Source: Elaborated by the authors.

\subsection{ENGAGEMENT OF MANAGERS IN SOCIAL MOVEMENTS}

In reflecting about the interface of the managers with other fields and types of capital, we also measure the engagement of them with social movements and once again the differences are striking among the four ministries. 


\section{GRAPH 13 PUBLIC MANAGERS, PARTICIPATION IN SOCIAL MOVEMENTS, PER GOVERNMENT (\%)} 1995-2012

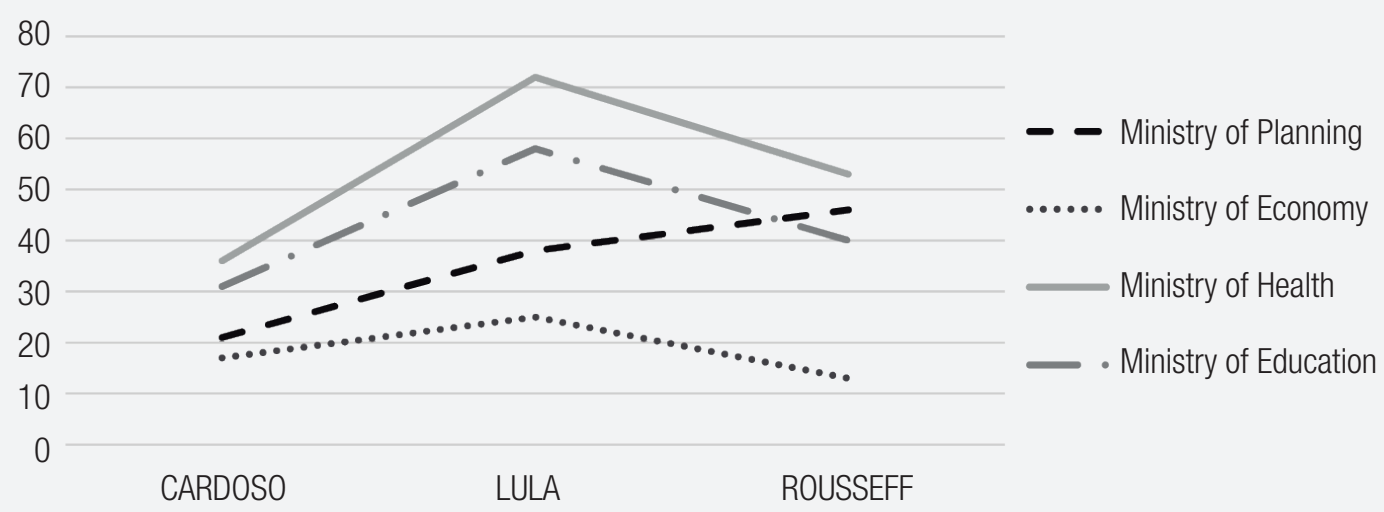

Source: Elaborated by the authors.

Graph 13 shows that the participation of public managers working in the Ministry of Economy in social movements is the lowest in all governments, and it is possible to observe this participation was not an upward commitment of the Workers' Party governments. There is a decline in the Dilma Rousseff government to a level below the ones observed in Cardoso and far below the levels during the term of Lula da Silva. Lula's administration stands out when it comes to participation of managers in social movements but, at the same time, it shows a continuous isolation of the economic area from connections with parties, unions and social movements.

\section{ADDITIONAL NOTES ON GENDER AND ETHNICITY}

Given the country's re-democratization scenario, it is worth commenting briefly on the gender and ethnicity variables in these four ministries. Women and Afro-descendants are still greatly absent in politics and in the Brazilian high administration. The data show that the presence of women, although very little, increased in the course of the three presidents' administrations, practically in a linear fashion, different from what is observed when it comes to ethnicity, as shown in graph 15. Note, however, that the Ministry of Economy has the least female representation.

The Ministry of Economy remains less open to women, but more open to Afro-descendants. The participation of this ethnic group grew significantly in the Ministries of Economy and Health. The former had been almost 100\% white during Cardoso administration. 


\section{GRAPH 14 WOMEN AS PUBLIC MANAGERS, PER MINISTRY AND GOVERNMENT (\%) 1995-2012}

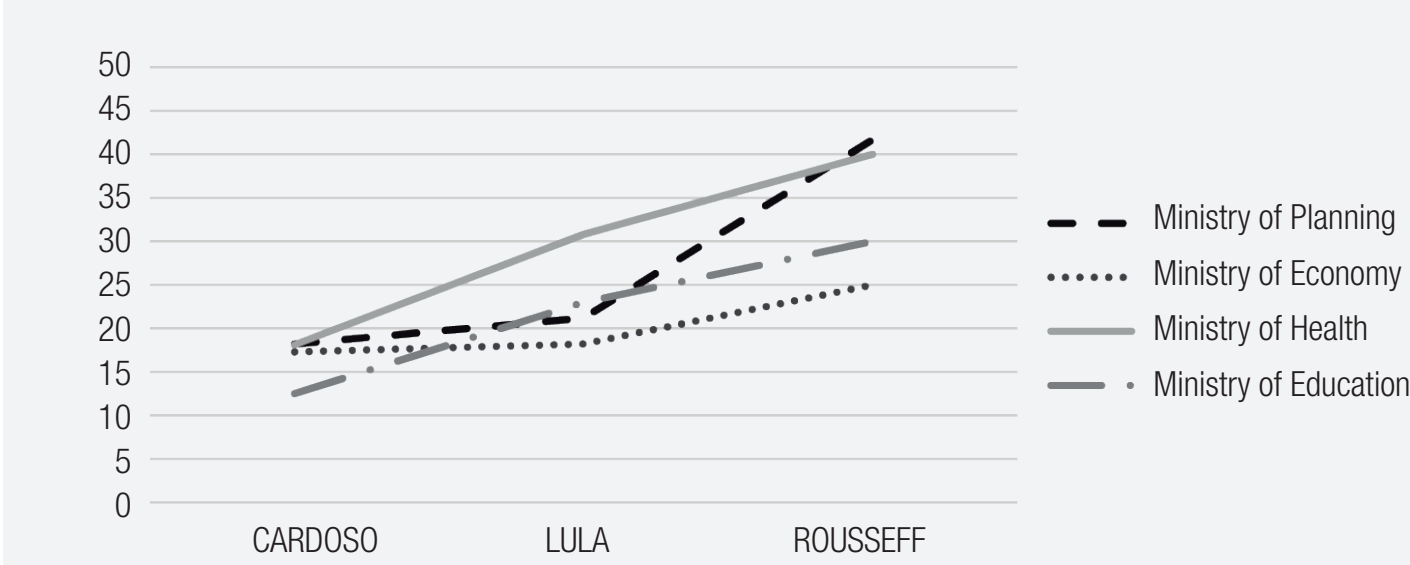

Source: Elaborated by the authors.

\section{GRAPH 15 NON-WHITE PUBLIC MANAGERS, PER GOVERNMENT (\%) 1995-2012}

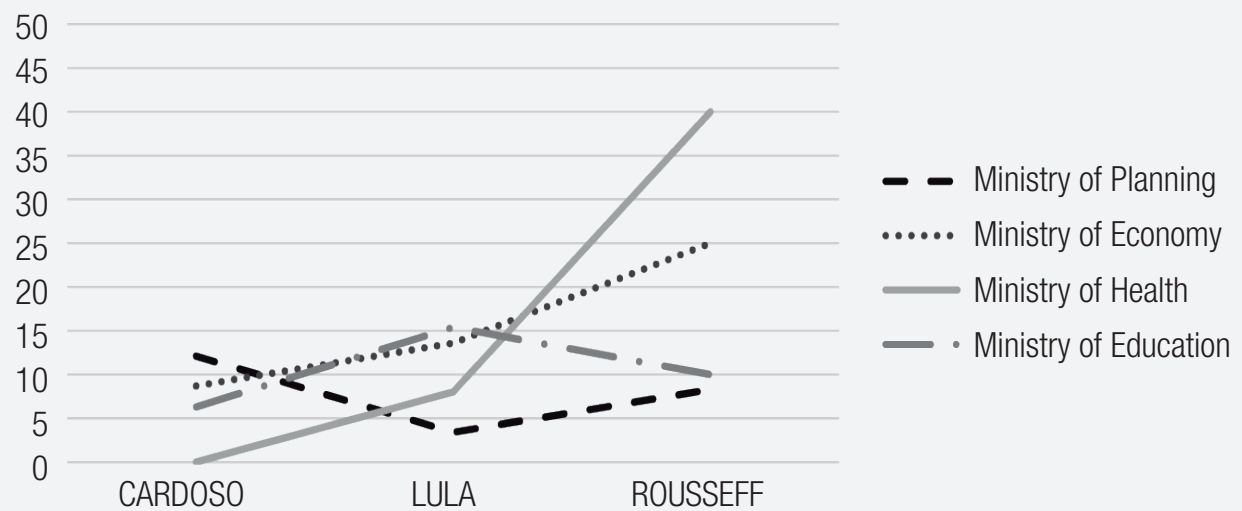

Source: Elaborated by the authors.

The two graphs show an improvement in the indicators of democratization of access for women and afro-descendants. An important point is that these two variables do not grow at the same speed in all ministries. Finally, throughout the period, the growth of women participation was more consistent than that of Afro-descendants. These are additional data to understand how the four ministries answered the question of social democratization, although they cannot be taken as a tendency for the whole public administration. 


\section{FINAL CONSIDERATIONS}

Despite differences between the three governments, and even considering that Lula da Silva administration stands out in several aspects of the analysis, the hypothesis that the 'financial' ministries have adopted different standards was demonstrated, but for reasons a little different from those found in the literature.

From the point of view of regional and functional recruitment, even with the constant predominance of the Southeast, it is noted that the strong presence of leaders coming from Brasília can indicate more solid careers in the federal government. Among the public servants who came to occupy appointed positions as managers in the economic area, those that already occupied functions in the federal public service predominated, which corroborates the previous affirmation. In the social area, the presence of public servants coming from states and municipalities to work in the ministries is significantly greater. It should be noted that the public servants from municipalities only took appointed positions in the federal government after Lula da Silva administration, evidencing the political capital of the Workers' Party at the local level and this president's decision to give visibility to these popular roots in the national scenario.

The literature on Brazil has insisted that the professionals in economic area would have a higher level of education than the ones in other areas, which is not what was found in this study. In fact, throughout all governments, the highest levels of education, from the point of view of formal academic qualification, were found in the ministries of Health and Education, with $100 \%$ of the managers holding PhD and Master degrees in Cardoso administration. Perhaps the more technical nature of the ministers related to economics explains the lesser emphasis on academic careers. Bourdieu (1989) noted that in France, the brightest students of the École Nationale d'Administration (ENA) are recruited to hold government positions related to the financial sector, while the ones with lower scores go to the social area. This, however, is a very different situation from Brazil, which does not have a school of this kind. Dispersed around the country are good public and Catholic universities to offer education for public service. Therefore, we focus our attention on the level of education. ${ }^{3}$

The education of parents is an important indicator to reflect about the social class of the public managers. Managers within the ministries of Health and Education have less educated parents in all three governments. The financial ministries, Economy and Planning, present the managers with parents with the highest rates of education. This is evidence to confirm the thesis that the nominees for the appointed positions in these ministries come from a higher social class. We can infer that this social capital of families encourages them to pursue more solid careers in the public service and not only an academic degree. On the other hand, in all cases, the jump in the education of fathers and mothers in relation to their children demonstrates the possibilities of social mobility in the country.

Considering affiliation to parties, the differences between the three governments are not great for the four ministries. The number, however, grows in the Workers' Party governments, but is still lower among the managers in the Ministry of Economy. The main difference lies in the variety of parties to which they are affiliated. Under the Cardoso administration, $48.8 \%$ of the party-affiliated managers belonged to the Brazilian Social Democratic Party, the president's party, while in the Lula

\footnotetext{
${ }^{3}$ Our research obtained data on the schools and programs attended by the managers. However, to keep to the scope of this article, they will be the object of a future work.
} 
da Silva and Dilma Rousseff governments these percentages reached $80 \%$ and $81.8 \%$, respectively. It is, therefore, a party recruitment mainly within the governing party, especially in the Workers' Party governments, which can be explained by the strong presence of the party affiliates in the public service.

When it comes to affiliation to trade unions or union federations, again the figures of Lula da Silva administration stand out, however with the maintenance of a pattern in the economic area. That is, the Ministries of Economy and Planning had less managers participating in trade unions. In the Cardoso government this ranged between $13 \%$ and $17 \%$ in the four ministries and in the Lula da Silva government rose to levels between $26 \%$ and $63 \%$. It significantly falls under the Rousseff government. When it comes to the presence of directors of trade union federations in the ministries, the Rousseff government practically returns to the level of Cardoso's. It is noted that Dilma Rousseff distanced from movements and organizations typical of Workers' Party grassroots, and this is especially clear when analyzing the interface with social movements in general.

The participatory boom of Lula da Silva does not repeat in the Rousseff administration. In any case, the important thing for this study is that, with the three presidents, the Ministry of Economy was the least subjected to this type of participation, which confirms the thesis of a more technical and insulated area, although with managers that have lower education level in comparison to other ministries.

In the Lula government, from what we have seen, various forms of capital are present in the process of filling appointed positions. It was a case that stood out by the fact that the partisan political capital and various forms of social capital in social and grassroots movements were triggered. In any case, the financial ministries were kept farer from this participatory dynamic, especially the Ministry of Economy.

Finally, this study shows some discrepancies between the managers in the analyzed ministries, but it also shows that the federal government has a qualified staff, regardless of recruitment differences. With this data, it is possible to reflect on how this personnel, so technically prepared, on the one hand, and so socially engaged, on the other hand, contribute to understanding the socio-genesis, the action and the organization of the Brazilian state.

As Bourdieu (2012) reminds, the bureaucratic field is not unrelated to the cultural specificities of each country, nor is it static. It has advances and retreats. The data examined clearly show changes as well as persistence. The persistency reside in the more technical and isolated profile of the economicfinancial area reflecting an important cultural aspect in the country, that is, the emphasis on economic progress, although often only as symbolic capital. This vision of progress should be pursued by people with exceptional technical capabilities, leading to the assumption that other areas of government action might be less qualified. In fact, and as shown throughout this study, this is not the case. In terms of academic qualification, the economic area is not the most expressive.

The country gradually formed a "state nobility", a highly educated staff. This expansion of personnel was greater in the areas of health and education, typical competences of social welfare policies that were often confused with clientele policies and irresponsible spending. Although the Brazilian literature has given more value to the insulated groups so far, or to groups of excellence related to industrialization, it is possible to start to infer that the country gradually builds specific capacities, or habitus, that conform practices and social spaces with their own structures, specific and relatively autonomous objectives in bureaucratic sectors beyond the economic area. 


\section{REFERENCES}

ABERBACH, Joel D.; PUTMAN, Robert D.; ROCKMAN, Bert A. Bureaucrats and politicians in western democracies. Cambridge: Harvard University Press, 1981.

ABERBACH, Joel D. Introduction: administration in an era of change. Governance, v. 16, n. 3, p. 315319, July 2003.

BENDIX, Reinhard. Transformações das sociedades europeias ocidentais desde o século XVIII. In: BENDIX, Reinhard. Construção nacional e cidadania: estudos de nossa ordem social em mudança. São Paulo: Edusp, 1996. p. 91-138.

BOURDIEU, Pierre. Esprits d'État [Genèse et structure du champ bureaucratique]. Actes de la Recherche en Sciences Sociales, n. 96-97, p. 49-62, Mar. 1993.

BOURDIEU, Pierre. Noblesse d'État: grandes écoles et esprit de corps. Paris: Les éditions de minuit, 1989.

BOURDIEU, Pierre. Sobre o Estado: cursos no Collége de France (1989-92). São Paulo: Companhia das Letras, 2012.

BOURDIEU, Pierre; CHIRISTEN, Oliveli; WILL, Pierre-Etienne. Sobre a ciência do Estado. Temáticas, n. 41, p. 251-265, Aug./Dec. 2012.

D’ARAUJO, Maria Celina. A elite dirigente do governo Lula. Rio de Janeiro: CPDOC/Fundação Getulio Vargas, 2009.

EVANS, Peter. Autonomia e parceria: Estados e transformação industrial. Rio de Janeiro: Editora UFRJ, 2004.

EVANS, Peter. O Estado como problema e solução. Lua Nova: Revista de Cultura e Política, n. 28-29, p. 107-157, 1993.

GEDDES, Barbara. Politician's dilemma: building state capacity in Latin America. Berkeley: University of California Press, 1994.

LAFER, Celso. O sistema político brasileiro. São Paulo: Perspectiva, 1975.

LOA LEI n ${ }^{\circ} 13.115$ de 20 de abril de 2015. Available at: <www.orcamentofederal.gov.br/clientes/portalsof/ portalsof/orcamentos-anuais/orcamento-2015-2/ arquivos-loa/anexo-ii-despesaorcamentofiscaleseg uridadesocialpororgaoorcamentario.pdf $>$. Accessed on: 17 Oct. 2016.
LONGO, Francisco. A consolidação institucional do cargo de dirigente público. Revista do Serviço Público, v. 54, n. 2, p. 7-33, Apr./June 2003.

LOPEZ, Félix; PRAÇA, Sérgio. Cargos de confiança, partidos políticos e burocracia federal. Riel - Revista Ibero-Americana de Estudos Legislativos, n. 4, p. 33-42, May 2015.

LOUREIRO, Maria Rita; ABRUCIO, Fernando Luiz; ROSA, Carlos A. Radiografia da alta burocracia federal brasileira: o caso do Ministério da Fazenda. Revista do Serviço Público - RSP, v. 49, n. 4, p. 46-82, Oct. 1998.

LOUREIRO, Maria Rita; OLIVIERI, Cecília; MARTES, Ana Cristina Braga. Burocratas, partidos e grupos de interesse: o debate sobre política e burocracia no Brasil. In: LOUREIRO, Maria Rita; ABRUCIO, Fernando Luiz; PACHECO, Regina Silvia (Org.). Burocracia e política no Brasil: desafios para o Estado democrático no século XXI. Rio de Janeiro: Editora FGV, 2010. p. 73-108.

MATHIAS, Suzeley Kalil. A militarização da burocracia: a participação do militar na administração federal das comunicações e da educação - 19631990. São Paulo: Unesp, 2004.

MINISTÉRIO DO PLANEJAMENTO, ORÇAMENTO E GESTÃO. Boletim estatístico de pessoal. Available at: <www.planejamento.gov.br/ assuntos/gestao-publica/arquivos-e-publicacoes/ BEP>. Accessed on: 1 Dec. 2017.

NUNES, Edson. A gramática política do Brasil: clientelismo e insulamento burocrático. Rio de Janeiro: Zahar, 1997.

SCHNEIDER, Ben. Burocracia pública e política industrial no Brasil. São Paulo: Sumaré, 1994.

SIMIONE, Albino Alves; MATOS, Fernanda. O campo em Bourdieu e a produção científica em administração pública no Brasil. Revista Espacios, v. 38, n 11, p. 1, 2017.

SULEIMAN, Ezra. Elites in French society: the politics of survival. Princeton: Princeton University Press, 1978.

THIRY-CHERQUES, Hermano Roberto. Pierre Bourdieu: a teoria na prática. Rev. Adm. Pública, Rio de Janeiro, v. 40, n. 1, p. 27-53, 2006. 


\section{Maria Celina D’Araujo}

$\mathrm{PhD}$ in Political Science, Professor of the Department of Social Sciences at the Pontifical Catholic University of Rio de Janeiro (PUC-Rio). E-mail: mariacelina@daraujo.net.

\section{Júlia Petek}

$\mathrm{PhD}$ Student in Social Sciences at the Pontifical Catholic University of Rio de Janeiro (PUC-Rio), Master in Science de la Population et du Développement from the Université Catholique de Louvain, Belgium.

E-mail: juliapetekfigueiredo@gmail.com. 